\title{
SOUKROMÍ V LATINSKÝCH A ČESKÝCH BIBLICKÝCH TEXTECH*
}

\author{
J O S E F Š I M A N D L
}

\section{ABSTRACT \\ Privacy in Czech and Latin biblical texts}

This paper ponders whether the notion of privacy should be seen as not biblical or not Catholic. Several Catholic encyclopedias were skimmed; the increasing interest in this topic is evident, although the prevailing point of view belongs not to theology or biblical studies, but to (ecclesiastical) law. In the following section of the paper, Czech words for privacy/private (soukromi/soukromy) in the Czech Ecumenical Translation and in the most notable older translation (Bible kralická) are examined and compared with their counterparts in Latin and Greek Bibles. The Old-Czech word súkromí with its strictly local sense is mentioned as well. To sum up: The examined words are plausibly used in the translation; the notion belongs to the biblical world and is worth of further research.

\section{Keywords}

Notion of privacy; Czech words for privacy; Biblical studies

DOI: $10.14712 / 23363398.2019 .10$

$\mathrm{M}_{\mathrm{o}}$ tivací k práci na příspěvku byl studentova námitka o nebibličnosti představy soukromí a soukromého, sdělená poté, co jsme se v biblickém překladu z 20. století setkali s užitím adjektiva soukromý. Je pravda, že zejména texty evangelií obsahují výzvu oprostit se od soukromého majetku: nejvýrazněji v Ježíšově radě prodej, co máś,

* Příspěvek vyšel z referátu předneseného 1. června 2018 na konferenci Jazyk a styl biblického prekladu: česká a polská perspektiva, oddělení starých jazyků Katedry biblických věd KTF UK. 
a rozdej chudým (Mt 19,21); nemáme také shromažd'ovat poklady na zemi, ale v nebi (Mt 6,19-20); i Ježíšovi učedníci jsou vysláni v krajní skromnosti (Mk 6,8-10). Přitom však Ježíšovo působení má nejen rozměr veřejný, jímž je vyučování v synagoze nebo promluvy k zástupům, které se kvůli Ježíšovi shromáždily, ale jeho integrální složkou jsou i návštěvy v soukromých domácnostech a setkávání s jednotlivci; vyprávění o uzdravení hluchoněmého (Mk 7,33) začíná slovy vzal si ho stranou, takže zázrak je vykonán v soukromí; Ježíš nás také nabádá, abychom s Bohem komunikovali prostřednictvím modlitby, půstu aj. nikoli tak, aby nás lidé viděli, ale v skrytu neboli v soukromí (o modlitbě Mt 6,6; o půstu Mt 6,18).

Tím se otvírá celý komplex otázek, z nichž vybíráme:

A. Patří představa soukromého k biblickému světu a ke katolické víře? Figuruje pojem soukromého/soukromí v katolických encyklopediích?

B. Co v latinském, popř. v novozákonním řeckém textu Bible odpovídá novočeským výrazům soukromý/soukromi? V čem se liší situace ve staročeských textech?

Existenci představy soukromého je z Bible jako celku doložena do té míry, že bez této představy by byla kompendiem jiné náboženské nauky a jiného pojímání světa. V úhelném kameni direktiv pro život člověka, v mojžíšském Desateru, máme přikázání Nepokradeš, které by bez existence soukromého vlastnictví nedávalo smysl. Osobní soukromí by bylo narušeno např́klad „odkrytím nahoty“ (Gn 9,22; Lv 18,7-9). Komunikace v soukromí, nikoli na veřejnosti, tzn. vzít si někoho stranou a tam s ním promluvit (Sk 23,19; Mt 18,15), ${ }^{2}$ se na řadě míst doporučuje nebo provádí jako vhodnější. Že i do soukromí mířila Ježíšova praxe a také jeho výzvy, to jsme už připomněli. Představa soukromého se tedy dotýká různých situací a tím je dána poměrně široká paleta vyjadřovacích možností, které bychom v úplnosti ani nemohli sledovat.

Katolické encyklopedie podávají dvojí svědectví: jednak že to či ono odedávna bylo soukromé, jednak že celkové uchopení pojmu soukromého je poměrně mladá záležitost. Tak např́klad New Catholic Encyclopedia ${ }^{3}$ která má pět svazků a tři série dodatků, uvádí ve svém rejstříku jen filozofický pojem Privation a heslo Private chapels. Podobně

2 Mt 18,15 podle ČEP: Když tvůj bratr zhřeší, jdi a pokárej ho mezi čtyřma očima. To má být první pokus řešení, a teprve selže-li, mají následovat pokusy „oficiálnější“ neboli (1) príiber $k$ sobé ješté jednoho nebo dva a zejména (2) oznam to církvi.

3 New Catholic Encyclopedia (Detroit: Thomson Gale, 2003-2011). 
Encyklopedia Katolick $a,{ }^{4}$ přestože její vydávání trvalo 41 let a odehrály se během něho zásadní proměny společnosti i věroučných akcentů, má jen hesla prywatne kościoły, prywatne objawienia. ${ }^{5}$

Nepoměrně širší zpracování představuje Lexikon für Theologie und Kirche (1957-1967), ${ }^{6}$ jehož dodatky zpracovávají nauku 2. vatikánského koncilu. Najdeme v něm podle rejstříku (tučně jsou uvedena samostatná hesla): Privat- -buße, -eigentum, -exorcismus, -geheimnis, -gelübde, Privation, -kapelle, -kapital(ismus), Privatklage, -messe, -offenbarung, -schulen, -versicherung a nádavkem Privattempelwesen jako germánské historické podloží pro Eigenkirche = ecclesia propria, srov. výše private chapels a prywatne kościoły. Jsou tu tedy popsány také nebiblické až moderní jevy ze života církve (nejen katolické) ve světě. Týž slovník ve svém revidovaném vydání (2009) má už komplexní heslo Privatsphäre, kde je v odkazech i monografie Kirche u. Datenschutz (Th. Hoeren; Essen 1986). ${ }^{8}$ Táž encyklopedie také připomíná, že podle pietistů nebo osvícenců je veškerý náboženský život soukromá záležitost. Podstatnější je, že až na heslo Privatsphäre se encyklopedická hesla zabývají soukromím ve smyslu (církevně)právním - nikoli ve smyslu teologickém, ba ani biblistickém.

Novočeské adjektivum soukromý má podle SSJČ ${ }^{9}$ poměrně široké použití:

soukromý (†soukromní Tyl, †soukromný Lum.) příd. privátní (op. veřejny) 1. jsoucí $\boldsymbol{v}$ majetku, péči, službách jednotlivce, nikoli veřejnosti, jednotlivce se týkající: s-é vlastnictví (výrobních prostředků); s-é firmy; s. sektor; s-é budovy, zahrady; s-á škola; s. ústav; s-é hodiny (vyučovací); s. učitel; s. pacient; s. učenec; s. podnikatel; s-é podnikání; s-á iniciativa; veř. spr. (dř.) s. zaměstnanec; práv. (dř.) s-é právo; s-á žaloba; s. žalobce; s. majetek; škol. (dř.) s. docent kt. není

\section{Encyklopedia Katolicka (Lublin: KUL, 1973-2014).}

5 Soukromá zjevení, tj. zjevení církví (zatím) neuznávaná, představují takovou dimenzi soukromého, která je stavěna do protikladu vůči obecně sdílené katolické víře.

6 Buchberger et al., Lexikon für Theologie u. Kirche (Freiburg: Herder, 1957-1967).

7 Lexikon für Theologie und Kirche, durchgesehene Ausgabe „Sonderausgabe“, ed. W. Kasper (Freiburg: Herder, 2009).

8 V době konání konference (viz pozn. 1) vrcholily mediální i institucionální aktivity spojené se zaváděním GDPR (General Data Protection Regulation) v Evropské unii, a tedy i v České republice. Stáří/zastaralost Hoerenovy monografie z předinternetové éry by bylo třeba zvážit; její existence však svědčí o tom, že postoji církve k ochraně dat jako $\mathrm{k}$ formě ochrany soukromí byla věnována pozornost už před třemi desetiletími. Slovnik spisovného jazyka českého (Praha: Academia, 1960-1971). 
zaměstnancem vysoké škkoly; úč. (dř.) s. účet osobni účet podnikatele n. společnika ve vlastním podniku 2. dějící se, konaný s vyloučením veřejnosti; osobni 4: s-é záležitosti; s-é listiny; s-é zájmy; úzce s. život intimní; s. rozhovor; s-á korespondence; s. telefonní hovor; to je moje s-é mínění; s. tisk (dř.) vydaný jednotlivcem pro omezený počet čtenář́i; jaz. s. projev neoficiální, neveřejný; ... (následují přihnízdovaná slova)

Tento přes půl století starý popis sice omezuje význam ,neoficiální ( $v$ soukromém rozhovoru přiznal, že ...) jen na sféru jazykovědy. Přesto lze významy adjektiva v zásadě shrnout do dvou vzájemně souvisejících významových okruhů: týkajici se jedince a vylučujici veřejnost; jejich vymezení se děje na základě akcentu položeného na jeden z komplementárních prvků významu.

Výskyt řetězce soukrom v Českém ekumenickém překladu Bible (dále ČEP) jsme vyšetřili podle internetového zdroje. ${ }^{10}$ Našlo se 7 míst, která lze podle významu adjektiva roztřídit takto:

- protikladný/komplementární k tomu, co se týká celé obce: 2 doklady, Mac;

- chránící intimitu: 1 doklad, Sir;

- pojmenovávající soukromé bydlení: 1 doklad, Act;

- vyjadřující situaci „zvlášt' od ostatních“ (může se týkat menší skupiny): 3 doklady, Mt, Mk, Ga.

Tato místa představíme nyní podrobněji, provnáme je se zněním ve Vulgatě ${ }^{11}$ (popř. také se zněním řeckým) a v Bibli kralické12 (dále BK).

Význam PROTIKLADNÝ/KOMPLEMENTÁRNí K TOMU, CO SE TÝKÁ CELÉ овСE má jednak 2Mak 4,5: vypravil se ke králi. Nechtél na obćany žalovat, ale mél na zréeteli prospèch obecný i soukromý všeho lidu. Ponèkud obtížněji srozumitelné vyjádření (soukromý prospěch všeho lidu?) má pandán ve Vulgatě communem utilitatem apud semet ipsum universae multitudinis considerans, který vychází z jiného znění/chápání

10 Bible - český ekumenický pŕeklad (60.-70. léta 20. století s pozdějšími dodatky). Prohledáváno na adrese https://www.bibleserver.com/search/CEP/soukrom/1 v květnu 2018. - Zvolený způsob vyhledávání pokrývá adjektivum soukromý a pokryl by také adverbium soukromé i substantivum soukromi, dále slova soukromnik, soukromnice, soukromničit, soukromoprávní. V ČEP se našlo jen adjektivum soukromý.

11 Vulgata: znění podle Vulgata Clementina, dostupné na http://cz.bibleserver.com; ověřeno 15. 10. 2018.

12 Bible kralická: znění podle Česká synoptická Bible (ČEP a BK) (Praha: ČBS, 2008) 
tohoto místa: výraz pro soukromé apud semet ipsum se logičtěji pojí s participiem considerans než $\mathrm{s}$ bezprostředně předcházejícím slovem utilitatem. BK má toto řešení: vypravil se k králi. Ne že by chtél na měštany žalovati, ale užitek obecný i obzvláštni (...) všeho množství opatruje. Vyjádření obzvláštní užitek je zavádějící a signalizuje překladatelský problém. V řeckém textu podle Septuaginty ${ }^{13}$ najdeme k onomu obecný

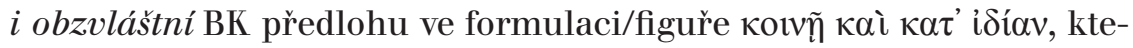
rá se zajisté užívala i o obecném a zvláštním, zde je však spíše užita o dobrodiních prokázaných obci i jednotlivcům.

Druhý doklad je 2Mak 9,26. ČEP má: Žádám vás tedy a prosím, abyste pamatovali na dobrodiní, obecná i soukromá, a zachovávali dosavadni náklonnost ke mné i k mému synovi. Vulgata na tomto místě má memores beneficiorum publice et privatim, takže pro označení soukromého užila slovo formálně asi nejbližší dnešnímu chápání. V BK stojí: Protož prosím vás i napomínam, abyšte pamatujice na ta dobrodiní, vỉbec i obzvláštné, jedenkaždý tu přitomnou pŕvétivost ke mné $i$ k synu zachovali. Tento překlad tedy opět uhýbá $\mathrm{z}$ dimenze veřejný $\times$ soukromý k dimenzi obecné $\times$ zvláštní - anebo, chcete-li, zpět k řec-

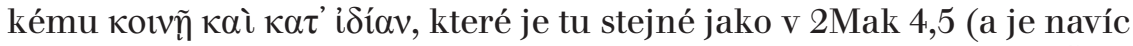
stejné i v Mk 4,34 - viz níže). Na obou místech ze 2 Mak pokročil ČEP od doslovnosti k interpretaci.

Význam chránící INTIMITU má Sír 29,21: Hlavni věc pro život je voda, chléb a odèv, i dům, který poskytuje soukromí. Vulgata toto místo podává takto: initium vitae aqua et panis et vestimentum et domus protegens turpitudinem, kde především obydlí přikrývá/ochraňuje mrzkost, přičemž vazba na substantivum vestimentum, oděv‘ je slabší, pokud ji vůbec uznáme; české vyjádření poskytuje soukromí lze v obou případech chápat jako eufemismus. BK má stejné místo označené jako 29,25 a textuje takto: Poćátek života lidského jest voda a chléb, dům a odév, kterýž přikrývá hanbu; tady je zakrývací funkce vztažena jen k oděvu, pokud odmítneme hypotézu neobratného překladu; soukromím se neoperuje, české vyjádření tu doslovně odpovídá latinskému pro-

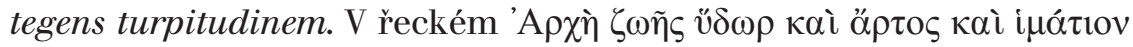

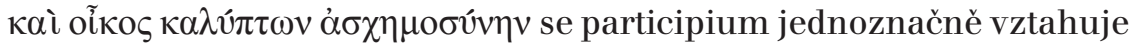
jen $\mathrm{k}$ příbytku díky tomu, že řecké participium $\kappa \alpha \lambda u ́ \pi \tau \omega \mathrm{v}$ má na rozdíl od latinského protegens tvary rozlišené rodem; nezapomeňme také na

13 Septuaginta, citováno podle https://www.academic-bible.com/en/online-bibles /septuagint-lxx/, ověřeno 15. 10. 2018. 
pořadí substantiv, které si BK upravila. Navíc protože funkci ochraňovat soukromí má spíš dům než oděv, zasluhuje způsob, jak se tu vyhnout slovu hanba/mrzkost ap., pochvalu.

Pojmenování souкRоме́но BYDLENí nalézáme také ve Sk 28,16. Toto místo zní v ČEP takto: Když jsme prišli do Řima, dostal Pavel dovolení, že může bydlet $\boldsymbol{v}$ soukromém bytè s vojákem, který ho bude hlidat. Vulgata má: permissum est Paulo manere sibimet cum custodiente eum

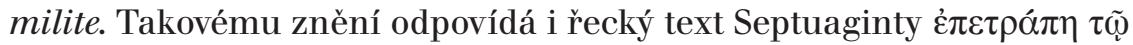

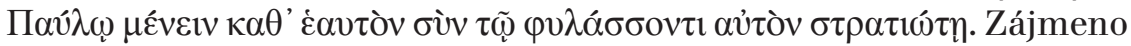
sám stačilo také překladatelům BK: Když jsme přišli do Říma, setník dal véznév moc hejtmanu vojska, ale Pavlovi dopušténo, aby sám bydlil $s$ žoldnérem, kterýž ho ostříhal. Řešení ČEP je tedy spíš výkladem než překladem a dosazuje znalost reálií, kterou sám překládaný text neobsahuje (soukromé bydlení důstojníků).

Na třech novozákonních místech se zkoumaný výraz vyskytuje ve významu zvlášŤ od ostatních. ${ }^{14}$ První je Mt 10,27: Co vám ríkám ve tmé, povézte na svétle; a co slyšíte v soukromí, hlásejte ze střech. Druhá část má ve Vulgatě podobu quod in aure auditis praedicate super tec-

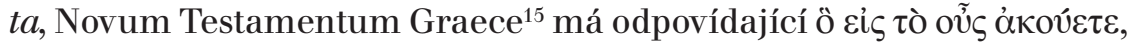

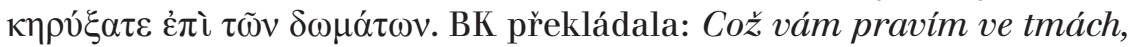
pravte na svétle, a co $v$ uši slyšite, hlásejte na domích. Na tomto místě udělal ČEP krok od metonymického vyjádření pomocí částí těla k pojmenování prostředí, které bylo soukromé.

Druhé místo je Mk 4,34: Bez podobenství k nim nemluvil, ale v soukromi svým učedníkům všecko vykládal. Setkáváme se tu s povážlivou, ale $\mathrm{v}$ evangeliích opakovaně poznamenanou skutečností jedné, méně jasné, náznakové nebo obrazné věrouky pro veřejnost a druhé s výkladem pro učedníky. Citovaný verš zní ve Vulgatě sine parabola autem non loquebatur eis, seorsum autem discipulis suis disserebat omnia; to

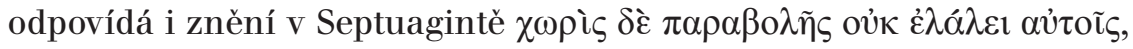

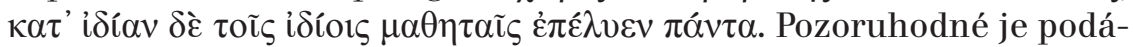
ní BK: Bez podobenství pak nemluvil jim, ale učedlníkům svým soukromi vykládal všechno; výraz soukromí je tu - odchylně od dnešní

14 Tomuto významu by se dalo podřadit i soukromé bydlení, ale kvůli odlišné situaci v textu jsme je vydělili zvlášt'.

15 Novum Testamentum Graece: ed. Nestle - Aland 28, dostupná v digitální podobě na https://www.academic-bible.com/en/online-bibles/novum-testamentum-graece-na -28; ověřeno 15. 10. 2018. 
češtiny - adverbiem, které znamená ,soukromě, v soukromí, jak odpovídá staročeskému stavu; viz o něm níže.

Třetí takové místo je Ga 2,2: Šel jsem tam na Boži pokyn a těm, kteři jsou ve zvláštni vážnosti, jsem v soukromi predložil evangelium, které zvěstuji pohanům, aby snad moje nynějš́ i dřivéjší úsilí nebylo nadarmo. Vyjadřuje se tu jednota obojího (soukromého i veřejného) znění evangelia, jak ho podával sv. Pavel. Onomu místu odpovídá ve Vulgatě Ascendi autem secundum revelationem, et contuli cum illis Evangelium, quod proedico in gentibus, seorsum autem iis qui videbantur aliquid esse : ne forte in vacuum currerem, aut cucurrissem a v Novum Testamentum

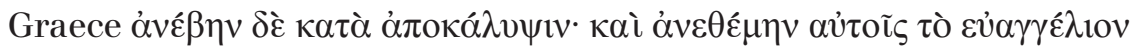

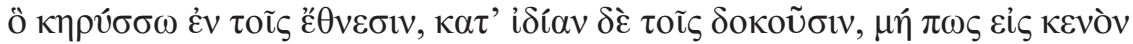

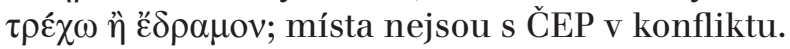

Než přikročíme $\mathrm{k}$ závěrům, věnujme pozornost výskytu řetězce súkrom- v excerpci, podle které se zpracovával Staročeský slovník. Výraz súkromie s platností příslovce - viz výše o Mk 4,34 v BK - má řadu výskytů ve staročeských biblích i v různých dobových výkladech biblického textu; kladl se nejčastěji na místa, kde bylo latinské seorsum, ${ }^{16}$ méně často za privatim, ${ }^{17}$ př́ležitostně se jím vyjádří to, co odpovídá latinskému slovesu recludere ,zavřít odděleně ${ }^{6}{ }^{18}$ nebo co odpovídá latinskému in conclavi,v pokoji, v obydlí pod uzavřením‘, jemuž odpovídá i náš významový okruh souкRомé BYDLENí. ${ }^{19}$ Několik dokladů ze 16. století má soukromnosti ,tajnosti, tajnůstky', např. slepé oko soukromností pokoutnich hledi a temností. ${ }^{20}$

Je tedy zřejmé, že staročeský úzus slova soukromi byl jiný než novočeský a pravděpodobně ještě jiné významové spektrum měly takové

16 Takové je mj. Mt 17,1 o vzetí učedníků na horu y wede gye na horu wisoku Sukromie (Nový zákon Kořečkův).

17 Jde o již představené místo Ga 2,2 kazi (=káži) lidem mezi pohani a Jukromie tiem, geff to se nyeczo zdachu abich snad darmo bil nebiehal nebo nebiezal (excerptum $\mathrm{z}$ nejasně datovaného spisu).

18 Lv 13,21: (kněz) zavret jej (malomocného) Jukromie za sedm dní/ recludet eum septem diebus (Bible pražská).

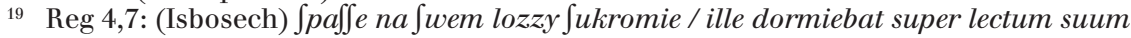
in conclavi (Bible olomoucká).

20 Doklady z tzv. doby střední jsou teprve ve zpracování, přičemž mnohdy jde o texty dosud nevydané, přístupné jen na technických nosičích; proto nejsou citovány s pramennými údaji. 
výrazy v době střední. Odlišnost osvětluje v hesle soukromí Machkův etymologický slovník: ${ }^{21}$

V starší době bylo soukromi = oddělené místo, samota (a adv. soukromí, -í jako v potaji) a soukromý, -ni (odtud soukromnik, -ice); nč. soukromý je mladší.

Závěrem shrňme: Dnešní chápání slov soukromí, soukromý se nekryje se staročeským a některá místa $\mathrm{BK},{ }^{22}$ přeložené $\mathrm{v}$ době střední, dokládají nechut' (i za cenu oslabení srozumitelnosti) užít slovo, jehož starý význam už nebyl jasný a nový význam, pokud se v té době vủbec objevoval, ještě nebyl pevný. Představa soukromí však není nic nekompatibilního ani s Písmem, ani se životem katolické církve v uplynulých dvou tisíciletích. Výrazy se v ČEP plauzibilně objevují

- jako ekvivalent seorsum ,stranou' (nejčastěji a tradičně);

- jako ekvivalent privatim ,odděleně‘;

- při náhradě konkrét chápaných spíš obrazně (BK: co v uši slyšíte);

- jako eufemismus (o přikrývání nahoty).

Představa soukromého jednak ve vztahu k Bibli, jednak ve vztahu k historii i současnému životu církve patří (zdá se ${ }^{23}$ mezi poměrně málo prozkoumaná témata, která zasluhují pozornost a také si ji postupně dobývají: viz exkurz o katolických encyklopediích. Z dalších zatím nevytěžených témat srov. Bartoň (2018). ${ }^{24}$

Katedra biblických véd Katolická teologická fakulta, Univerzita Karlova

Thákurova 3 160 00, Praha 6 E-mail: josef.a.simandl@gmail.com

21 Machek, Václav: Etymologický slovník jazyka českého (Praha: Academia, 1971).

22 Jde zejména o obě místa z knih Makabejských: 2Mak 4,5 a 9,26.

25 To nejobvyklejší v dnešních časech, totiž internetové vyhledávání publikací o soukromém/soukromí v Bibli, naráží na vážný problém v tom, že kdekterá stránka obsahující texty z Bible nebo o Bibli obsahuje také ustanovení o sítové ochraně soukromí zvané zpravidla Privacy Policy. Najdou se internetové texty na sledované téma, namnoze vyvolané potřebou vyrovnat se s GDPR (srov. pozn. 8), např. https:// www.quora.com/What-does-the-Bible-say-in-regards-to-privacy-and-privacy-rights (navštíveno 15. 10. 2018) - ale to nejsou teologické studie.

24 Josef Bartoň, „Tekst biblijny i sprawy ,zbyt powszednie‘? Na marginesie kwestii tabu językowego w tradycji czeskiego przekładu biblijnego,“ Poznańskie Studia Polonistyczne. Seria Językoznawcza 25, č.1 (2018), s. 11-32. 